\title{
Effect of Pedagogical Formation Program on Pre-Service History Teachers' Perceived Self-Efficacy
}

\author{
Fatih Yazici * \\ Gaziosmanpasa University, TURKEY
}

\author{
Tercan Yildirim \\ Giresun University, TURKEY
}

Received: June 16, 2017 - Revised: July 7, 2017 - Accepted: July 10, 2017

\begin{abstract}
The purpose of the present study is to investigate pre-service history teachers' perceived self-efficacy and the effect of pedagogical formation training on this perception. The study is based on a one-group pretest-posttest research design, which is a type of pre-experimental design. For the purpose of the study, in the first week of the formation training, the "Teachers' Sense of Efficacy Scale" developed by Tschannen-Moran and Hoy and adapted to Turkish by Capa, Cakiroglu and Sarikaya was administered as a pre-test to a group of 178 pre-service history teachers who underwent pedagogical formation training in 2016-2017 academic year in two different universities in Turkey. The same scale was administered again as a post-test at the end of the 28-week training. The study has found out that the pedagogical formation training did not make a significant difference in pre-service history teachers' perceived self-efficacy except for the classroom management subscale, in which the self-efficacy scores of pre-service history teachers decreased after the pedagogical formation training.
\end{abstract}

Keywords: Self-efficacy, history education, pedagogical formation program, pre-service teachers.

To cite this article: Yazici, F., \& Yildirim, T. (2017). Effect of Pedagogical Formation Program on Pre-Service History Teachers' Perceived Self-Efficacy. European Journal of Educational Research, 6(3),357-366. doi: 10.12973/eu-jer.6.3.357

\section{Introduction}

It is an undeniable fact that there is a need for a qualified teaching process in order for the education system to respond to social needs. The effectiveness of teaching processes is directly related to the efficacy of teacher and the quality of classroom practices. In fact, there is a linear relationship between the success of an educational institution and the professional competencies of its teachers (Aydemir, 2012). Many factors that range from teachers' professional competencies to their behavior and from their worldviews to their values influence students and thus educational processes (Arastaman, 2013; Ay, 2007; Karagozoglu et al., 1995; Senemoglu, 2001).

The need for a qualified teacher for the effectiveness of learning-teaching process has also led to the identification of various competencies for teachers. The Ministry of National Education (2006) defines the concept of competence as the knowledge, skills, attitudes and values that one must have in order to fulfill the teaching profession effectively and efficiently and such competencies are categorized as personal competency, field competency, and educational competency. Personal competence refers to high personal responsibility, creativity, the ability to solve problems, critical thinking, working in teams, initiating change, understanding, compassion and tolerance as well as high social relationships and moral values. Field competence means that a particular quality and quantity of relevant professional knowledge is required in a particular field of knowledge. Educational competence is associated with a teacher's educational work, especially with teaching (Sunbul, 2006 as cited in Caliskan, Isik \& Saygin, 2013).

For a qualified education, particular attention should be paid to subject matter knowledge besides professional teaching knowledge. Indeed, Shulman discusses that field knowledge, curriculum knowledge, and pedagogical content knowledge are main determinants although the importance of such professional knowledge is undeniable (cited in Oner, 2010). Shulman $(1986,1987)$ argues that although a teacher closely follows all innovations in the method, technique or pedagogy, s/he builds it on the knowledge of subject matter. The related literature contains several studies that support this claim and draw attention to the importance of subject matter knowledge within the context of teacher competencies (Akcay, 2009; Barton \& Levstik, 2004; Kincal, 2004; Oner, 2010; Ozdemir, Yalin \& Sezgin, 2004; Smith, 2010).

\footnotetext{
* Corresponding author:

Fatih Yazici , Gaziosmanpasa University, Department of Social Science Education, Tokat / Turkey

$\square$ fatih.yazici@gop.edu.tr
} 
In addition to teachers' and pre-service teachers' subject matter knowledge competencies, their personality traits, their skills to teach learning and use technology, classroom management skills, planning and assessment skills and communication and guidance skills are also important elements of teacher training process (Seker et al., 2005: 240). Apart from all these skills, teachers' and pre-service teachers' personal judgments about their abilities and skills are of crucial importance in overcoming problems encountered during teaching processes (Demirtas, Comert \& Ozer, 2011; Ozdemir, 2008). In other words, pre-service teachers need to feel competent in knowledge, skills and experience so that they can provide an effective teaching service throughout their professional life. This attitude, which is referred to as perceived self-efficacy, is influential on professional success (Kurt, 2012).

Perceived self-efficacy or self-efficacy belief is a concept related to individual judgments about how well individuals can perform actions necessary to cope with possible problems they may encounter. This concept, first used by Albert Bandura in the context of Social Cognitive Theory, is defined as individuals' belief, perception and judgment of their capacity to organize and successfully perform activities and/or actions necessary to demonstrate a certain performance. In other words, self-efficacy is a belief about the trust that an individual has in himself and in his ability to attain the desired outcome in any given situation (Bandura, 1977, 1986, 1994, 1997). Self-efficacy does not refer to the ability to perform an action but rather the belief in the ability to do it and occurs before starting an action (Zimmerman, 2000).

Tschanen-Moran and Woolfolk-Hoy (2001) define teachers' self-efficacy as a teacher's belief in his/her capacity or ability to produce desirable learning outcomes. It is emphasized that this belief is highly influential on the achievement of curriculum objectives and on the learning, performance and motivation of a person (Bandura, 1977, 1986, 1994, 1997).

According to the Social Cognitive Theory, a teacher with high perceived self-efficacy will plan and carry out an effective teaching process based on the belief that people's beliefs affect their behaviors (Ay, 2007). In fact, it is of increasing importance that teachers and pre-service teachers have positive judgments about their knowledge and skills to deal with problems already encountered or to be encountered and to engage in qualified teaching (Ozdemir, 2008). In short, any kind of positive judgment that an individual has about his or her own abilities seems to be very important for the teaching profession. From this point of view, teachers need not only field knowledge and pedagogical knowledge but also a belief in their ability to present them effectively (Arastaman, 2013).

The high perceived self-efficacy of teachers is one of the factors that increase motivation in classroom practices and thus student achievement (Capri \& Kan, 2006; Gibson \& Dembo, 1984). As teachers with high perceived self-efficacy are self-confident above all, they make various plans to organize learning settings, identify learning strategies and involve students in decision-making processes (Gencturk \& Memis, 2010). Accordingly, Goddard et al. (2004) argue that teachers who believe in their self-efficacy tend to be more student-centered and to determine strategies they use in the teaching-learning process by taking students into consideration since their decisions about classroom practices stem from their sense of competence.

When teacher's self-efficacy is low, the commitment to teaching processes is also low. This causes less time to be spent on the lectured subjects and the specified objectives not to be achieved. All this brings about the lack of discipline, motivation and success (Ashton \& Webb, 1986). Therefore, teachers become more withdrawn instead of overcoming this negative situation. This may result in discharge or resignation from work (Bandura, 1997).

Just as in the teaching of every field, there are responsibilities expected of teachers in history teaching. Apart from having field knowledge, history teachers are also responsible for knowing how their students will learn history (Husbands, Kitson \& Pendry, 2003; Husbands, 2011; Nichol \& Dean, 2005). John (1991) classifies and defines teachers' responsibilities for teaching history in three categories including knowledge of history, knowledge of teaching history and knowledge of 'education' as follows: 
Table 1. Defining and Describing History Teachers' Professional Craft Knowledge

Knowledge of history
History teachers' thinking is
knowledge (fact)-driven
History teachers' knowledge is
organized and structured by tasks
they have encountered in the
classroom
Knowledge is semi-permanent and
is influenced by teachers'
values/beliefs/attitudes

Knowledge of teaching history

Pedagogical content knowledge: pivotal knowledge about how to teach history, e.g. approaches to topics, structuring approaches, knowledge of underlying concepts and procedures

Knowledge of teaching, strategies -

role plays group work, etc.

is influenced by
values/beliefs/attitudes

History as events/topics/ personalities: this knowledge is developmental, cumulative, acquisitive

\section{Curriculum knowledge \\ Knowledge of texts \\ Syllabus/curricular requirements}

expectations/

Resources

\section{Knowledge of 'education'}

Knowledge of learning

How children learn and specific problems/issues surrounding how pupils learn history

The teacher's view/understanding of the process of learning history

What learning history involves/looks like

What appropriate learning activities are

Why some activities are more effective

Knowledge of the institution

Contextual knowledge of school, department, class

The pastoral element

Institutional knowledge enables the teacher to be an effective member of the school community
Knowledge is informed by teachers' understanding of the process of history and historical writing

Knowledge is the foundation of and principally responsible for informing planning, expectations, resources, teaching strategies

$\begin{array}{lr}\text { Knowledge helps } & \text { to } \\ \text { diagnose/understand } & \text { pupil } \\ \text { misconceptions } & \end{array}$

Organizational knowledge

Organizing classes/groups, school visits

Technical/professional/managerial aspects

History teachers in Turkey are trained in two different ways. The first way of training happens through departments of history teaching at faculties of education and aims to help pre-service teachers acquire the aforementioned knowledge and skills as a whole through different courses taught in these departments. The second and more common way involves cases where last-grade students or graduates of faculties of science and letters receive pedagogical formation training. The last way of training requires pre-service teachers to acquire the knowledge of history at history departments of faculties of science and letters but the knowledge of teaching history and knowledge of 'education' through the pedagogical formation training. Thus, pedagogical formation training holds a vital position for history teachers' self-efficacy and perceived self-efficacy.

It is possible to find many studies in the international literature related to the concept of self-efficacy, which is of utmost importance for teacher qualifications within the above-mentioned conceptual framework (Ashton \& Webb, 1986; Bandura, 1977, 1986, 1994, 1997; Caprara et al., 2006; Gibson \& Dembo, 1984; Goddard et al., 2000; Guskey, 1988, 1994; Guskey \& Passaro, 1994; Pajares, 1997; Tschannen-Moran, Woolfolk Hoy \& Hoy, 1998). In recent years, important research has also been carried out in Turkey to determine teachers' or pre-service teachers' levels of selfefficacy (Arastaman, 2013; Askar \& Umay, 2001; Ay, 2007; Aypay, 2010; Bikmaz, 2004; Capri \& Kan, 2006; Ekici, 2008; 
Kilinc, 2011; Kurt, 2012; Ozdemir, 2008; Taskin \& Haciomeroglu, 2010; Tunca \& Sahin, 2014; Tuluk, 2015; Ustuner, Demirtas, Comert \& Ozer, 2009; Yenice, 2012; Yilmaz et al., 2004).

There are only a few studies on history teachers' perceived self-efficacy. These studies focus on the preparation process of history teacher special field competencies (Candeger, 2014), the level of courses taught at history teaching departments to satisfy such competencies (Candeger, 2013), pedagogical field knowledge (Bal, 2011; Bal \& Karademir, 2013; Bozkurt, 2015), and technological pedagogical content knowledge (Bozkurt, 2016). As can be seen, there is no research in Turkey on perceived self-efficacy of history teachers or pre-service history teachers. Thus, the purpose of the present study is to investigate pre-service history teachers' perceived self-efficacy and the effect of pedagogical formation training on this perception. The study also aims to identify different variables that are influential on preservice history teachers' perceived self-efficacy.

\section{Methodology}

\section{Research Method}

This research is based on a one-group pretest-posttest design, which is a type of pre-experimental design (Karasar, 1995). In the one-group pretest-posttest design, a group selected by purposive sampling is exposed to the independent variable, and a measurement tool is applied both as a pre-test and as a post-test. The "Teachers' Sense of Efficacy Scale" was administered as a pre-test in the first week of the formation training in order to examine the effect of pedagogical formation training on pre-service teachers' perceived self-efficacy. At the end of the 28-week training period, the "Teachers' Sense of Efficacy Scale" was administered again as a post-test. The study examined whether there was a difference between the perceived self-efficacy scores of the two measures.

\section{Sample Group}

The sample consists of 178 pre-service history teachers who underwent pedagogical formation training in 2016-2017 academic year in two different universities in Turkey. 109 (61\%) of the participants are female and 69 (39\%) are male. 116 participants were regular high school graduates, 23 were Anatolian high school graduates, 26 were vocational high school graduates, 6 were Imam-Hatip high school graduates, and 4 were open high school graduates. Considering the reasons for their choice of the department from which they graduated or will graduate, 115 participants chose their department at their own will, 32 chose not to be idle (unemployed), and 7 chose at the wish of their parents. Considering their GPA (grade point average) based on a 100-point scale system, 4 participants had a GPA of 54-63, 43 had a GPA of 64-74, 105 had a GPA of 75-86, and 24 had a GPA of 87-100. 87 (49\%) of the participants thought of doing a job other than teaching while $38(21 \%)$ did not have such a thought. 53 participants (22\%) remained undecided on this issue. 68 (38\%) participants did not think they could be assigned as a teacher while 45 (25\%) thought that they could be assigned as a teacher. 64 participant (36\%) remained undecided on this issue.

\section{Data Collection}

The "Teachers' Sense of Efficacy Scale" (TSES) developed by Tschannen-Moran and Hoy (2001) and adapted to Turkish by Capa, Cakiroglu and Sarikaya (2005) was used as data collection tool. This 24-item scale is composed of three subscales including Student Engagement, Instructional Practices, and Classroom Management. It is a 5-point Likerttype scale involving "nothing", "very little", "some influence", "quite a bit", and "a great deal". The Cronbach's alpha coefficients for the subscales are .82, .86, and .84, respectively. According to the results of the analysis on the data in the present study, the Cronbach's alpha reliability values for the subscales were found to be $.80, .85$, and. 83 , respectively. The value is .92 for the entire scale.

\section{Data Analysis}

The research data were analyzed using SPSS 20 software. The mean and standard deviation values of the perceived self-efficacy of pre-service history teachers were calculated within the framework of the research. The t-test was used in the comparison of the pre-service teachers' pre-test and post-test scores and in the evaluation of these scores according to gender, university of study, and GPA.

\section{Findings}

In order to determine the effect of pedagogical formation training on pre-service history teachers' perceived selfefficacy, t-test was performed to compare the pre-test scores recorded at the beginning of pedagogical formation training and the post-test scores recorded at the end of training. The analysis results are presented in the table below. 
Table 2. The t-test Results of the Pre-Test and Post-Test Scores for Pre-Service History Teachers' Perceived Self-Efficacy

\begin{tabular}{|c|c|c|c|c|c|}
\hline Subscales and Total Score & Groups & $\overline{\mathbf{X}}$ & Sd & $\mathbf{t}$ & $\mathbf{p}$ \\
\hline \multirow{2}{*}{ Student Engagement } & Pretest & 3.83 & .52 & \multirow{2}{*}{.689} & \multirow{2}{*}{.492} \\
\hline & Posttest & 3.79 & .52 & & \\
\hline \multirow{2}{*}{ Instructional Strategies } & Pretest & 3.80 & .57 & \multirow{2}{*}{1.567} & \multirow{2}{*}{.118} \\
\hline & Posttest & 3.69 & .56 & & \\
\hline \multirow{2}{*}{ Classroom Management } & Pretest & 3.89 & .58 & \multirow{2}{*}{2.258} & \multirow{2}{*}{$.025^{*}$} \\
\hline & Posttest & 3.73 & .58 & & \\
\hline \multirow{2}{*}{ Total } & Pretest & 3.84 & .49 & \multirow{2}{*}{1.363} & \multirow{2}{*}{.174} \\
\hline & Posttest & 3.75 & .50 & & \\
\hline
\end{tabular}

${ }^{*} \mathrm{p}<.05$

Given the pre-test and post-test scores for pre-service history teachers' perceived self-efficacy in Table 2, there is no significant difference in the first two subscales and in the total score of the scale while there is a significant difference at $\mathrm{p}<.05$ in the classroom management subscale. Accordingly, pre-service history teachers' post-test scores for the classroom management are lower than their pre-test scores, and this difference is statistically significant. Considering the other subscales and the total score of the scale, the post-test scores are also lower than the pre-test score at p>.05.

The pre-test and post-test scores for pre-service history teachers' perceived self-efficacy were compared by gender using t-test. The analysis results are presented in the table below.

Table 3. Comparison of the Pre-Test and Post-Test Scores for Teachers' Perceived Self-Efficacy by Gender

\begin{tabular}{|c|c|c|c|c|c|c|}
\hline Subscales and Total Score & Groups & Gender & $\overline{\mathbf{X}}$ & Sd & $t$ & $\mathbf{p}$ \\
\hline \multirow{2}{*}{ Student Engagement } & Pretest & $\begin{array}{l}\text { Female } \\
\text { Male }\end{array}$ & $\begin{array}{l}3.79 \\
3.89\end{array}$ & $\begin{array}{l}.54 \\
.47\end{array}$ & -1.238 & .218 \\
\hline & Posttest & $\begin{array}{l}\text { Female } \\
\text { Male }\end{array}$ & $\begin{array}{l}3.73 \\
3.93\end{array}$ & $\begin{array}{l}.52 \\
.50\end{array}$ & -2.013 & $.048^{*}$ \\
\hline \multirow{2}{*}{ Instructional Strategies } & Pretest & $\begin{array}{l}\text { Female } \\
\text { Male }\end{array}$ & $\begin{array}{l}3.78 \\
3.83\end{array}$ & $\begin{array}{l}.60 \\
.53\end{array}$ & -.541 & .590 \\
\hline & Posttest & $\begin{array}{l}\text { Female } \\
\text { Male }\end{array}$ & $\begin{array}{l}3.61 \\
3.89\end{array}$ & $\begin{array}{l}.55 \\
.55\end{array}$ & -2.565 & $.012^{*}$ \\
\hline \multirow[t]{2}{*}{ Classroom Management } & Pretest & $\begin{array}{l}\text { Female } \\
\text { Male }\end{array}$ & $\begin{array}{l}3.84 \\
3.96\end{array}$ & $\begin{array}{l}.62 \\
.52\end{array}$ & -1.358 & .176 \\
\hline & Posttest & $\begin{array}{l}\text { Female } \\
\text { Male }\end{array}$ & $\begin{array}{l}3.63 \\
3.94\end{array}$ & $\begin{array}{l}.59 \\
.51\end{array}$ & -3.035 & $.003^{*}$ \\
\hline \multirow{2}{*}{ Total } & Pretest & $\begin{array}{l}\text { Female } \\
\text { Male }\end{array}$ & $\begin{array}{l}3.81 \\
3.89\end{array}$ & $\begin{array}{l}.55 \\
.41\end{array}$ & -1.028 & .306 \\
\hline & Posttest & $\begin{array}{l}\text { Female } \\
\text { Male }\end{array}$ & $\begin{array}{l}3.67 \\
3.94\end{array}$ & $\begin{array}{l}.51 \\
.44\end{array}$ & -2.937 & $.004^{*}$ \\
\hline
\end{tabular}

As seen in Table 3, pre-service history teachers' perceived self-efficacy did not differ significantly by gender both in three subscales of student engagement, instructional strategies and classroom management and in the total score of the scale. However, considering the post-test scores, there is a significant difference in three subscales and the total score of the scale. Accordingly, the post-test scores of male participants for student engagement, instructional strategies and classroom management are higher than those of female participants, and this difference is significant. A significant differentiation in the same direction is also observed in the total score of the scale. According to the analysis results, although the post-test scores of female pre-service history teachers for three subscales and the total score are lower than their pre-test scores, the post-test scores of male participants are higher than their pre-test scores for the total score and two subscales apart from classroom management. However, this difference is not significant at $\mathrm{p}<.05$.

In order to determine the effect of the university on pre-service teachers' perceived self-efficacy, the scores for both universities were compared using $t$-test. These two universities were coded as A and B for ethical reasons. The analysis results are presented in Table 4. 
Table 4. Comparison of the Pre-Test and Post-Test Scores for Teachers' Perceived Self-Efficacy by the University of Study

\begin{tabular}{|c|c|c|c|c|c|c|}
\hline Scale Dimensions and Total Score & Groups & University & $\overline{\mathbf{X}}$ & Sd & $t$ & $\mathbf{p}$ \\
\hline \multirow{3}{*}{ Student Engagement } & Pretest & $\begin{array}{l}\text { A } \\
B\end{array}$ & $\begin{array}{l}3.91 \\
3.75\end{array}$ & $\begin{array}{l}.44 \\
.58\end{array}$ & 1.930 & .055 \\
\hline & \multirow{2}{*}{ Posttest } & A & 3.89 & .49 & \multirow{2}{*}{2.003} & \multirow{2}{*}{$.048^{*}$} \\
\hline & & B & 3.71 & .53 & & \\
\hline \multirow{3}{*}{ Instructional Strategies } & Pretest & $\begin{array}{l}\mathrm{A} \\
\mathrm{B}\end{array}$ & $\begin{array}{l}3.92 \\
368\end{array}$ & .51 & 2.752 & $.007^{*}$ \\
\hline & \multirow{2}{*}{ Posttest } & A & 3.77 & .55 & \multirow{2}{*}{1.369} & \multirow{2}{*}{.174} \\
\hline & & B & 3.64 & .57 & & \\
\hline \multirow{3}{*}{ Classroom Management } & Pretest & $\begin{array}{l}\text { A } \\
\text { B }\end{array}$ & $\begin{array}{l}4.02 \\
3.75\end{array}$ & $\begin{array}{l}.51 \\
.62\end{array}$ & 3.083 & $.002^{*}$ \\
\hline & \multirow{2}{*}{ Posttest } & A & 3.78 & .58 & \multirow{2}{*}{.782} & \multirow{2}{*}{.436} \\
\hline & & B & 3.70 & .59 & & \\
\hline \multirow{3}{*}{ Total } & \multirow[t]{2}{*}{ Pretest } & A & 3.95 & .44 & \multirow{2}{*}{2.961} & \multirow{2}{*}{$.004^{*}$} \\
\hline & & B & 3.72 & .54 & & \\
\hline & Posttest & $\begin{array}{l}A \\
B\end{array}$ & $\begin{array}{l}3.85 \\
2.60\end{array}$ & .47 & 1786 & .077 \\
\hline
\end{tabular}

${ }^{*} \mathrm{p}<.05$

Given the pre-test results in Table 4, there is a significant difference in the total score and two subscales apart from student engagement in favor of University A. Accordingly, the pre-test scores of pre-service history teachers getting pedagogical formation training in University A for the instructional strategies, the classroom management and the total score are higher at $\mathrm{p}<.05$ than the pre-test scores of those getting pedagogical formation training in University $\mathrm{B}$. However, based on the post-test results, there is a significant difference at $\mathrm{p}<.05$ only in the student engagement subscale. Thus, the post-test scores of pre-service history teachers getting training in University A for student engagement are higher than the post-test scores of those getting training in University B.

In order to determine the effect of pre-service history teachers' undergraduate GPA on their perceived self-efficacy, their GPA was categorized into two groups as "74 and below" and "75 and above". The scores for both categories were compared using t-test. The analysis results are presented in Table 5.

Table 5. Comparison of the Pre-Test and Post-Test Scores for Teachers' Perceived Self-Efficacy by GPA

\begin{tabular}{|c|c|c|c|c|c|c|}
\hline Subscales and Total Score & Groups & Grade Average & $\overline{\boldsymbol{X}}$ & Sd & $t$ & $\mathbf{p}$ \\
\hline \multirow{2}{*}{ Student Engagement } & Pretest & $\begin{array}{l}74 \text { and below } \\
75 \text { and above }\end{array}$ & $\begin{array}{l}3.82 \\
3.84\end{array}$ & $\begin{array}{l}.63 \\
.48\end{array}$ & -.195 & .846 \\
\hline & Posttest & $\begin{array}{l}74 \text { and below } \\
75 \text { and above }\end{array}$ & $\begin{array}{l}3.79 \\
3.79\end{array}$ & $\begin{array}{l}.52 \\
.52\end{array}$ & .087 & .931 \\
\hline \multirow{2}{*}{ Instructional Strategies } & Pretest & $\begin{array}{l}74 \text { and below } \\
75 \text { and above }\end{array}$ & $\begin{array}{l}3.80 \\
3.79\end{array}$ & $\begin{array}{l}.61 \\
.57\end{array}$ & .030 & .976 \\
\hline & Posttest & $\begin{array}{l}74 \text { and below } \\
75 \text { and above }\end{array}$ & $\begin{array}{l}3.69 \\
3.71\end{array}$ & $\begin{array}{l}.59 \\
.54\end{array}$ & -.058 & .954 \\
\hline \multirow[t]{2}{*}{ Classroom Management } & Pretest & $\begin{array}{l}74 \text { and below } \\
75 \text { and above }\end{array}$ & $\begin{array}{l}3.96 \\
3.87\end{array}$ & $\begin{array}{l}.64 \\
.56\end{array}$ & .788 & .434 \\
\hline & Posttest & $\begin{array}{l}74 \text { and below } \\
75 \text { and above }\end{array}$ & $\begin{array}{l}3.74 \\
3.75\end{array}$ & $\begin{array}{l}.58 \\
.58\end{array}$ & -.089 & .929 \\
\hline \multirow{2}{*}{ Total } & Pretest & $\begin{array}{l}74 \text { and below } \\
75 \text { and above }\end{array}$ & $\begin{array}{l}3.84 \\
3.84\end{array}$ & $\begin{array}{l}.59 \\
.47\end{array}$ & -.023 & .982 \\
\hline & Posttest & $\begin{array}{l}74 \text { and below } \\
75 \text { and above }\end{array}$ & $\begin{array}{l}3.78 \\
3.75\end{array}$ & $\begin{array}{l}.49 \\
.51\end{array}$ & .293 & .770 \\
\hline
\end{tabular}

As seen in Table 5, participants' GPA did not lead to a difference in the pre-test and post-test scores for perceived selfefficacy. This applies to both three subscales and the total score of the scale. 


\section{Discussion and Conclusion}

Pedagogical formation training that enables graduates of faculties other than faculties of education in Turkey to become secondary school branch teachers has led to many debates since it was put into force by the Council of Higher Education (YOK). These discussions are centered on teacher employment and teacher qualifications (Altinkurt, Yilmaz \& Erol, 2014; Azar, 2011; Celikten, Sanal \& Yeni, 2005; Kaya, Harurloglu, Keser \& Horoz, 2011; Sural \& Saritas, 2015). The present study examining the effect of pedagogical formation training on pre-service history teachers' perceived self-efficacy also allows pedagogical formation training to be considered in the context of teacher qualifications.

According to the research results, pedagogical formation training did not lead to a significant difference in pre-service history teachers' perceived self-efficacy except for the classroom management subscale. Pre-service history teachers' perceived self-efficacy scores on classroom management subscale decreased at the end of the pedagogical formation training. This result can be associated with (non)quality of pedagogical formation training given in Turkey and can be interpreted as teacher training given in a short period like one year is insufficient and does not have a positive effect on self-efficacy, which is one of the basic concepts concerning teacher qualifications, but rather has adverse effects due to some of its aspects. In fact, pre-service history teachers may not have had extensive knowledge of concepts concerning teachers' self-efficacy included in the scale at the beginning of pedagogical formation training when the pre-test was administered and therefore, they may have felt self-efficacy in teaching. In the course of the pedagogical formation training, pre-service history teachers began to gain experience in teaching for the first time through courses such as Special Teaching Methods and found opportunities to improve their teaching experience in real classes of secondary school students through the Teaching Practice course. This may have made pre-service history teachers become aware in which areas of the teaching profession they are inadequate. In fact, in various studies, perceived self-efficacy and teaching motivation of pre-service teachers getting pedagogical formation training have been found to be higher than faculty of education students, who are normally expected to have a better command of educational concepts and have more teaching experience thanks to different internship courses (Altinkurt, Yilmaz \& Erol, 2014; Bagceci, Yildirim, Kara \& Keskinpalta, 2015). As it is known, high perceived self-efficacy has a paradoxical meaning as it both shows the selfconfidence felt for professional competence and has a negative potential for teachers not to improve themselves and eliminate their deficiencies. In this sense, it is possible to say that pedagogical formation training has an effect of increasing pre-service history teachers' awareness of self-efficacy.

Analyzing pre-service history teachers' self-efficacy according to gender, the study has found out that perceived selfefficacies of male and female participants were close at the beginning of the pedagogical formation training. However, at the end of the training, perceived self-efficacy of male participants was found to be statistically significantly higher than that of female participants with respect to the subscales and the total score of the scale. Thus, it seems that pedagogical formation training has a more positive effect on perceived self-efficacy of male pre-service teachers compared to female pre-service teachers. This result seems to be consistent with that of other studies in the literature in that male teachers or pre-service teachers have higher self-efficacy than female teachers or pre-service teachers (Elkatmis, Demirbas \& Ertugrul, 2013; Demirtas, Comert \& Ozer, 2011; Morgil, Secken \& Yucel, 2004). However, there are studies that have results in favor of female teachers and/or pre-service teachers (Capri \& Celikkaleli, 2008; Ilgaz, Bulbul \& Cuhadar, 2013; Ozdemir, 2008; Sural \& Saritas, 2015) and other studies showing that gender is not a determinant of teachers' self-efficacy (Azar, 2010; Gencturk \& Memis, 2010; Cakir, Kan \& Sunbul, 2006; Kahyaoglu \& Yangin, 2007; Ustuner, Demirtas, Comert \& Ozer, 2009). Considering all these results together, it is difficult to generalize the effect of gender on teacher self-efficacy. However, the result of the present study that male pre-service teachers had higher self-efficacy at the end of the pedagogical formation training can be associated with self-confidence and stronger self-esteem expected of men within the context of gender roles.

According to the research results, there was a difference between two universities with respect to pre-service teachers' perceived self-efficacy measured before the pedagogical formation training; however, this difference disappeared after the pedagogical formation training. Accordingly, it appears that the pedagogical formation training given in both universities has a similar effect on teachers' self-efficacy and a similar nature in terms of quality.

Another result of the research is that undergraduate GPAs of pre-service history teachers did not make a significant difference in the pre-test and post-test scores. This result indicates that pre-service history teachers' knowledge of history they gained during their undergraduate education did not have an effect on their perceived self-efficacy and thus, field knowledge and perceived self-efficacy are different concepts. 


\section{References}

Akcay, S. (2009). Ilkogretim fen bilgisi ogretmen adaylarinin biyoloji alan bilgisi yeterliligi [Primary education science teacher trainees the adequacy of knowledge in the subject area of biology]. PhD Thesis, University of Gazi, Ankara.

Altinkurt, Y., Yilmaz, K. \& Erol, E. (2014). Pedagojik formasyon programi ogrencilerinin ogretmenlik meslegine yonelik motivasyonlari [Pedagogic formation program students' motivations for teaching profession]. Trakya Universitesi Egitim Fakultesi Dergisi, 4(1), 48-62.

Arastaman, G. (2013). Egitim ve fen edebiyat fakultesi ogrencilerinin oz-yeterlik inanclari ve ogretmenlik meslegine karsi tutumlarinin incelenmesi [Examination of education and arts and sciences faculty students' self-efficacy beliefs and their attitudes toward teaching profession]. Ahi Evran Universitesi Kirsehir Egitim Fakultesi Dergisi, 14(2), 205-217.

Ashton, P. T. \& Webb, R. B. (1986). Making a difference: Teachers' sense of efficacy and student achievement. New York: Longman.

Askar, P. \& Umay, A. (2001). Ilkogretim matematik ogretmenligi ogrencilerinin bilgisayarla ilgili oz-yeterlik algisi [Perceived computer self-efficacy of the students in the elementary mathematics teaching program]. Hacettepe Universitesi Egitim Fakultesi Dergisi, 21, 1-8.

Ay, B. (2007). Ogretmenlerin oz-yeterlikleri ve orgutsel vatandaslik davranisi [Teacher's self-efficacy and organizational citizenship behavior]. Master Thesis, University of Afyon Kocatepe.

Aydemir, H. (2012). Sosyal bilgiler ogretmenlerinin ogretim yontem, teknik ve stratejileri kullanma yeterlikleri [Competencies of social sciences teachers in using teaching methods]. Hikmet Yurdu, 5(9), 81-100.

Aypay, A. (2010). Genel oz yeterlik olcegi'nin (goyo) Turkce'ye uyarlama calismasi [The adaptation study of general self-efficacy (GSE) scale to Turkish]. Inonu Universitesi Egitim Fakultesi Dergisi, 11(2), 113-131.

Azar, A. (2010). Ortaogretim fen bilimleri ve matematik ogretmeni adaylarinin oz yeterlik inanclari [Pre-service secondary science teachers' self-efficacy beliefs about science teaching]. ZKU Sosyal Bilimler Dergisi, 6(12), 235252.

Azar, A. (2011). Turkiye'deki ogretmen egitimi uzerine bir soylem: Nitelik mi, nicelik mi [Quality or quantity: A statement for teacher training in Turkey]. Yuksekogretim ve Bilim Dergisi, 1(1), 36-38, doi: 10.5961/jhes.2011.004

Bagceci, B., Yildirim, I., Kara, K. \& Keskinpalta, D. (2015). Pedagojik Formasyon ve Egitim Fakultesi Ogrencilerinin Ogretmenlik Meslegine Yonelik Tutumlarinin Karsilastirilmasi [A comparative study on the attitudes of students from education faculties and science faculties towards being a teacher]. Erzincan Universitesi Egitim Fakultesi Dergisi, 17(1), 307-324, doi: http://dx.doi.org/10.17556/jef.52416

Bal, M. S. (2011). Tarih ogretmen adaylarinin Hacli Seferleri konusunda pedagojik alan bilgilerinin incelenmesi [Examining the pre-service history teachers' pedagogical content knowledge regarding the Crusades]. Selcuk Universitesi Ahmet Kelesoglu Egitim Fakultesi Dergisi, 31, 239-261.

Bal, M. S. \& Karademir, N. (2013). Sosyal bilgiler ogretmenlerinin teknolojik pedagojik alan bilgisi konusunda ozdegerlendirme seviyelerinin belirlenmesi [Determining social science teachers' self-assessment levels with regard to their technological pedagogical content knowledge]. Pamukkale Universitesi Egitim Fakultesi Dergisi, 34(2), 15-32.

Bandura, A. (1977). Self-efficacy: Toward a unifying theory of behavioral change. Psychological Review, 84, $191-215$.

Bandura, A. (1986). Social foundations of thought and action: A social cognitive theory. Englewood Cliffs, NJ: PrenticeHall.

Bandura, A. (1994), Self-efficacy. In V. S. Ramachaudran (Ed.), Encyclopedia of Human Behavior (4) (pp. 71-81). Newyork: Academic Press.

Bandura, A. (1997). Self- efficacy: The exercise of control. New York: Freeman.

Barton, K. C. and Levstik, L. S. (2004). Teaching history for the common good. Mahwah: Lawrence Erlbaum Associates.

Bikmaz, F. H. (2004). Oz yeterlik inanclari [Self-efficacy beliefs]. In Y. Kuzgun \& D. Deryakulu (Eds.), Egitimde Bireysel Farkliliklar (pp. 289-314). Ankara: Nobel Yayin Dagitim.

Bozkurt, N. (2015). Tarih ogretmeni ozel alan yeterlik algilarinin degerlendirilmesi [Determining the history teacher candidates' efficacy in the special field competencies]. Usak Sosyal Bilimler Dergisi, 8(3), 65-86. 
Bozkurt, N. (2016). Tarih ogretmeni adaylarinin teknolojik pedagojik alan bilgisine yonelik ozguvenlerinin belirlenmesi [Determination of self-confidence for technological pedagogical content knowledge of pre-service history teacher]. Mustafa Kemal Universitesi Sosyal Bilimler Enstitusu Dergisi, 13(33), 153- 167.

Cakir, O., Kan, A. \& Sunbul, O. (2006). Ogretmenlik meslek bilgisi ve tezsiz yuksek lisans programlarinin tutum ve ozyeterlik acisindan degerlendirilmesi [The evaluation of the teaching certificate program and the masters program without thesis with respect to students' attitudes and self-efficacy]. Mersin Universitesi Egitim Fakultesi Dergisi, 2(1), 36-47.

Caliskan, M., Isik, A. N. \& Saygin, Y. (2013). Ogretmen adaylarinin ideal ogretmen algilari [Prospective teachers' perception of ideal teacher]. Ilkogretim Online, 12(2), 575-584.

Candeger, U. (2013). Universitelerin tarih ogretmenligi bolumlerinin internet sayfalarinda bulunan ders programlari ile tarih ogretmeni ozel alan yeterliklerinin karsilastirilmasi [Comparison of special area competences and course programs in web pages of history teacher departments]. Usak Universitesi Sosyal Bilimler Dergisi, Ozel Sayi, 329346.

Candeger, U. (2014). Tarih ogretmeni ozel alan yeterliklerinin hazirlanmasi [Preparation of history teacher special field competences]. Turk Tarih Egitimi Dergisi, 4(1), 177-194.

Capa, Y., Cakiroglu, J. \& Sarikaya, H. (2005). Ogretmen ozyeterlik olcegi Turkce uyarlamasinin gecerlik ve guvenirlik calismasi [The development and validation of a turkish version of the teachers' sense of efficacy scale]. Egitim ve Bilim, 30(137), 74-81.

Caprara, G. V., Barbaranelli, C., Steca, P. \& Malone, P. S. (2006). Teachers' self-efficacy beliefs as determinants of job satisfaction and students' academic achievement: A study at the school level. Journal of School Psychology, 44, 473490.

Capri, B. \& Kan, A. (2006). Ogretmen kisilerarasi oz-yeterlik olceginin turkce formunun gecerlik ve guvenirlik calismasi [The teacher interpersonal self-efficacy scale: Validity and reliability study of Turkish form]. Mersin Universitesi Egitim Fakultesi Dergisi, 2(1), 48-61.

Capri, B., \& Celikkaleli, O. (2008). Ogretmen adaylarinin ogretmenlige iliskin tutum ve mesleki yeterlik inanclarinin cinsiyet, program ve fakultelerine gore incelenmesi [Investigation of preservice teachers' attitudes towards teaching and professional self-efficacy beliefs according to their gender, programs, and faculties]. Inonu Universitesi Egitim Fakultesi Dergisi, 9(15), 33-53.

Celikten, M., Sanal, M. \& Yeni, Y. (2005). Ogretmenlik meslegi ve ozellikleri [Teaching profession and its features]. Erciyes Universitesi Sosyal Bilimler Enstitusu Dergisi, 19 (2), 207-237.

Demirtas, H., Comert, M., \& Ozer, N. (2011).Ogretmen adaylarinin oz yeterlik inanclari ve ogretmenlik meslegine iliskin tutumlari [Pre-service teachers' self-efficacy beliefs and attitudes towards profession]. Egitim ve Bilim, 36(159), 96-111.

Ekici, G. (2008). Sinif yonetimi dersinin ogretmen adaylarinin ogretmen oz-yeterlik algi duzeyine etkisi [The effects of the classroom management lesson on preservice teachers' teacher sense of self-efficacy]. Hacettepe Universitesi Egitim Fakultesi Dergisi, 35, 98-110.

Elkatmis, M., Demirbas, M. \& Ertugrul, N. (2013). Egitim fakultesi ogrencileri ile formasyon egitimi alan fen edebiyat fakultesi ogrencilerinin ogretmenlik meslegine yonelik oz yeterlik inanclari [Self-efficacy beliefs of students who take the pedagogic training program in the faculty of arts and sciences and students in the education faculty towards teaching profession]. Pegem Journal of Education \& Instruction, 3 (3), 41-50.

Gencturk, A. \& Memis, A. (2010). An investigation of primary school teachers' teacher efficacy and job satisfaction in terms of demographic factors. Elementary Education Online, 9(3), 1037-1054.

Gibson, S. \& Dembo, M. H. (1984). Teacher efficacy: A construct validation. Journal of Educational Psychology, 76, 569582.

Goddard, R. D., Hoy, W. K. \& Woolfolk-Hoy, A. W. (2000). Collective teacher efficacy: Its meaning, measure, and impact on student achievement. American Educational Research Journal, 37(2), 479-507.

Goddard, R. D., Hoy, W. K. \& Woolfolk-Hoy, A. W. (2004). Collective efficacy beliefs: Theoretical developments, empirical evidence, and future directions. Educational Researcher, 33(3), 3-13.

Guskey, T. R. (1988). Teacher efficacy, self-concept, and attitudes toward the implementation of instructional innovation. Teaching and Teacher Education, 4, 63-69.

Guskey, T. R. \& Passaro, P.D. (1994), Teacher efficacy: A study of construct dimensions. American Educational Research Journal, 31, 627-643. 
Husbands, C. (2011). What do history teachers (need to) know? A framework for understanding and developing practice. In I. Davies (Ed.), Debates in history teaching, (pp. 84-95), Routledge: London.

Husbands, C., Kitson, A. \& Pendry, A. (2003). Understanding history teaching: Teaching and learning about the past in secondary schools. Philadelphia: McGraw-Hill Education.

Ilgaz, G., Bulbul, T. \& Cuhadar, C. (2013). Ogretmen adaylarinin egitim inanclari ile oz-yeterlik algilari arasindaki iliskinin incelenmesi [Investigation of the relationship between pre-service teachers' educational beliefs and their perceptions of self-efficacy]. Abant Izzet Baysal Universitesi Egitim Fakultesi Dergisi, 13 (1), 50-65.

John, P. (1991). The professional craft knowledge of the history teacher. Teaching History, 64, 8-12

Kahyaoglu, M., \& Yangin, S. (2007). Ilkogretim ogretmen adaylarinin mesleki oz yeterliklerine iliskin gorusleri [Views of prospective teachers in elementary school teaching departments about professional self-efficacy]. Kastamonu Egitim Dergisi, 15(1), 73-84.

Karagozoglu, G., Arici, H., Bulbul, S. \& Coker, N. (1995). Turkiye'de ogretmen egitim politikalari ve modelleri: Avrupa konseyi ulkeleri ogretmen yetistirme politikalari ve modelleri toplantisi [Teacher education policies and models in Turkey: Council of Europe countries meeting of teacher training policies and models] . Ankara: Milli Egitim Basimevi.

Karasar, N. (1995). Bilimsel arastirma yontemi [Scientific research model]. Ankara: Nobel Yayin Dagitim.

Kaya, E., Harurloglu, Y., Keser, S. \& Horoz, A. (2011). Fen ve edebiyat fakultesi ogrencilerine verilen formasyon hakkina egitim fakultesi ogrencilerinin bakisi [Faculty of education students' views to formation right given to faculty of science and letters students]. Dogu Cografya Dergisi, 16 (26), 213-222.

Kilinc, M. (2011). Ogretmen adaylarinin egitimde olcme ve degerlendirmeye yonelik ozyeterlik algi olcegi [a perceptual scale for measurement and evaluation of prospective teachers self-efficacy in education]. Ahi Evran Universitesi Kirsehir Egitim Fakultesi Dergisi, 12(4), 81-93.

Kincal, R. (2004). Ogretmenlik meslegine giris [An introduction to teacher profession]. Istanbul: Nobel Akademi Yayincilik.

Kurt, T. (2012). Ogretmenlerin oz yeterlik ve kolektif yeterlik algilari [Self-efficacy and collective-efficacy perceptions of teachers]. Turk Egitim Bilimleri Dergisi, 10(2), 195-227.

Ministry of National Education (2006). Ogretmenlik meslegi genel yeterlikleri [General competencies of teacher profession]. otmg.meb.gov.tr/belgeler/Yeterlikler.doc

Morgil, I., Secken, N. \& Yucel, A. S. (2004). Kimya Ogretmen Adaylarinin Ozyeterlik Inanclarinin Bazi Degiskenler Acisindan Incelenmesi [Investigation of self-efficacy beliefs of chemistry teacher candidates in terms of some variables]. Balikesir Universitesi Fen Bilimleri Enstitusu Dergisi, 6(1), 62-72.

Nichol, J. \& Dean, J. (2005). History 7-11: Developing primary teaching skills. London: Routledge.

Oner, D. (2010). Ogretmenin bilgisi ozel bir bilgi midir? Ogretmek icin gereken bilgiye kuramsal bir bakis [Is teacher's knowledge a special kind of knowledge? A theoretical view on the subject matter knowledge needed for teaching]. Bogazici Egitim Dergisi, 27(2), 23-32.

Ozdemir, S. M. (2008). Sinif ogretmeni adaylarinin ogretim surecine iliskin oz- yeterlik inanclarinin cesitli degiskenler acisindan incelenmesi [An investigation of prospective primary teachers' self-efficacy beliefs regarding teaching process in terms of certain variables]. Kuram ve Uygulamada Egitim Yonetimi, Bahar (54), 277-306.

Ozdemir, S., Yalin, H.I. \& Sezgin, H. (2004). Ogretmenlik meslegine giris [An introduction to teacher profession]. Ankara: Nobel Yayincilik.

Pajares, F. (1997). Current directions in self-efficacy research. In M. Maehr \& P. R. Pintrich (Eds.), Advances in motivation and achievement, Vol. 10, (pp. 1-49). Greenwich, CT: JAI Pres.

Seker, H., Deniz, S. \& Gorgen, I. (2005). Tezsiz yuksek lisans ogretmen adaylarinin ogretmenlik yeterlikleri uzerine degerlendirmeleri [Prospective teachers' assessment of teacher competencies]. Kuram ve Uygulamada Egitim Yonetimi, (42), 237-253.

Senemoglu, N. (2001). Gelisim, ogrenme ve ogretim [Development, learning and teaching]. Ankara: Gazi Kitabevi.

Shulman, L. S. (1986). Those who understand: knowledge growth in teaching. Educational Researcher, 15(2), 4-14.

Shulman, L.S. (1987). Knowledge and teaching: foundations of new reform. Harvard Educational Review, 57(1), 1-22

Smith, N. (2010). The history teacher's handbook. New York: Continuum International Publishing Group. 
Sural, S. \& Saritas, E. (2015). Pedagojik formasyon programina katilan ogrencilerin ogretmenlik meslegine yonelik yeterliklerinin incelenmesi [The investigation of the students of pedagogical formation the towards teaching profession qualifications]. Mersin Universitesi Egitim Fakultesi Dergisi, 11(1), 76-96.

Taskin, C. S. \& Haciomeroglu, G. (2010). Ogretmen ozyeterlik inanc olceginin turkceye uyarlanmasi ve sinif ogretmeni adaylarinin ozyeterlik inanclari [Adaptation of the teachers' efficacy beliefs system-self form and primary teachers' self-efficacy beliefs]. Dokuz Eylul Universitesi Buca Egitim Fakultesi Dergisi, 27, 63-75.

Tschannen-Moran, M. \& Woolfolk-Hoy, A. (2001). Teacher efficacy: Capturing an elusive construct. Teaching and Teacher Education, 17, 783-805.

Tschannen-Moran, M., Woolfolk-Hoy, A. \& Hoy, W. K. (1998). Teacher efficacy: Its meaning and measure. Review of Educational Research, 68, 202-248.

Tuluk, G. (2015). Ogretmen adaylarinin ogretmen oz-yeterlilikleri uzerine bir inceleme [An analysis regarding the selfefficacy of prospective teachers]. Usak Universitesi Egitim Arastirmalari Dergisi, 1(1), 1-15.

Tunca, N. \& Sahin, S. A. (2014). Ogretmen adaylarinin bilis otesi (ust bilis) ogrenme stratejileri ile akademik oz yeterlik inanclari arasindaki iliski [The relationship between pre-service teachers' metacognitive learning strategies and academic self-efficacy]. Anadolu Journal of Educational Sciences International, 4(1), 47-56.

Ustuner, M., Demirtas, H., Comert, M. \& Ozer, N. (2009). Ortaogretim Ogretmenlerinin Oz-Yeterlik Algilari [Secondary School Teachers' Self-Efficacy Beliefs]. Mehmet Akif Ersoy Universitesi Egitim Fakultesi Dergisi, 9(17), 1-16.

Yenice, N. (2012). Ogretmen adaylarinin oz-yeterlik duzeylerinde problem cozme becerilerinin incelenmesi [Investigating the self-efficacy and problem solving skills of preservice teachers]. Elektronik Sosyal Bilimler Dergisi, 11(39), 36-58.

Yilmaz, M. Koseoglu, P. Gercek, C. \& Soran, H. (2004). Ogretmen oz-yeterlik inanci [Teacher self-efficacy belief]. Bilim ve Aklin Aydinliginda Egitim Dergisi, 58.

Zimmerman, B. J. (1995). Self-efficacy and educational development. Self-efficacy in changing societies. New York: Cambridge University Press. 